\title{
PENGARUH KECEMASAN BERKOMUNIKASI TERHADAP PRESTASI AKADEMIK MAHASISWA JURUSAN PENDIDIKAN BIOLOGI ANGKATAN 2013 FAKULTAS TARBIYAH DAN KEGURUAN UIN ALAUDDIN MAKASSAR
}

\author{
Sofyan $^{(1)}$, Muh. Rapi ${ }^{(2)}$, Ahmad Afiif ${ }^{(3)}$ \\ Jurusan Pendidikan Biologi Fakultas Tarbiyah dan Keguruan UIN Alauddin Makassar, \\ Kampus II Jl. H. M. Yasin Limpo No. 36 Samata-Gowa, Sulawesi Selatan 92118, \\ E-mail: sofyanramli7@gmail.com, 085342002927
}

\begin{abstract}
Abstrak
Penelitian ini bertujuan untuk mengetahui Kecemasan Berkomunikasi Mahasiswa Jurusan Pendidikan Biologi Angkatan 2013 Fakultas Tarbiyah dan Keguruan UIN Alauddin Makassar, untuk mengetahui Prestasi Akademik Mahasiswa Jurusan Pendidikan Biologi Angkatan 2013 Fakultas Tarbiyah dan Keguruan UIN Alauddin Makassar, dan untuk mengetahui Pengaruh Kecemasan Berkomunikasi terhadap Prestasi Akademik Mahasiswa Jurusan Pendidikan Biologi Angkatan 2013 Fakultas Tarbiyah dan Keguruan UIN Alauddin Makassar.

Jenis penelitian ini adalah deskriptif kuantitatif. Populasi dalam penelitian ini adalah seluruh mahasiswa angkatan 2013 Jurusan Pendidikan Biologi Fakultas Tarbiyah dan Keguruan UIN Alauddin Makassar berjumlah 120 mahasiswa sedangkan sampelnya adalah $50 \%$ dari populasi berjumlah 60 mahasiswa dengan teknik pengambilan sampel "Simple Random Sampling". Instrumen yang digunakan dalam penelitian ini adalah skala kecemasan berkomunikasi dan dokumentasi dalam bentuk indeks prestasi semester (I dan II). Teknik analisis yang digunakan adalah analisis statistik deskriptif dan analisis statistik inferensial. Berdasarkan hasil analisis statistik deskriptif, kecemasan berkomunikasi diperoleh nilai rata-rata 82,73 berada pada kategori sedang dari nilai ideal 100 diperoleh nilai terendah 60, nilai tertinggi 110 dengan presentase 68,33\%. Untuk hasil prestasi akademik diperoleh nilai rata-rata 3,34 berada pada kategori memuaskan dari nilai ideal 4,00 diperoleh nilai terendah 2,28, nilai tertinggi 4,00 dengan presentase $70 \%$. Adapun hasil analisis statistik inferensial dengan uji regresi sederhana, diperoleh koefisien korelasi nilai $f_{\text {hitung }}$ sebesar 13,139 sedangkan nilai $f_{\text {tabel }}(5 \%)(\mathrm{df}=58)$ sehingga $f_{\text {tabel }}=3,16$. Jadi, dapat disimpulkan bahwa $f_{\text {hitung }}>f_{\text {tabel }}$ yakni $13,139>3,16$, maka $H_{0}$ ditolak dan $H_{1}$ diterima yang berarti terdapat pengaruh yang positif antara kecemasan berkomunikasi terhadap prestasi akademik mahasiswa Jurusan Pendidikan Biologi Angkatan 2013 Fakultas Tarbiyah dan Keguruan UIN Alauddin Makassar dengan sumbangsih sebesar 18,5 $\%$.
\end{abstract}

Kata kunci: Kecemasan berkomunikasi, Prestasi Akademik 


\begin{abstract}
The purpose of this research is to know The Students' Communication Anxiety of Biology Education Department 2013 in Tarbiyah and Teaching Science Faculty of Alauddin State Islamic University of Makassar, and to know The Effect ofStudents' Communication Anxiety of Biology Education Department 2013 in Tarbiyah and Teaching Science Faculty of Alauddin State Islamic University of Makassar

The type of this research is quantitative descriptive. Population in this research is the whole students of Biology Education Department 2013 in Tarbiyah and Teaching Science Faculty of Alauddin State Islamic University of Makassar in aggregate 120 students, while the sample is 50\% from the population in aggregate 60 students by using "Simple Random Sampling" technique. The instrument of this research is psychology scale of communication anxiety and documentation in the first and the second semester achievement index form. Analysis technique that uses is descriptive statistic analysis and inference statistic analysis.

According to the result of descriptive statistic analysis, the communication anxiety gets average score 82,73 in medium category from ideal score 100 gets the lowest score 60 , and the highest score is 110 with presentation 68,33\%. For the result of academic achievement gets average score 3,34 in satisfy category from ideal score 4,00 gets the lowest score 2,28, the highest score is 4,00 with presentation 70\%. The result of inference statistic analysis with simple regression test, gets score correlation coefficient $f_{\text {hitung }} 13,139$ while the score of $f_{\text {tabel }}(5 \%)(\mathrm{df}=58)$ so that $f_{\text {tabel }}=3,16$. So, the conclusion means that

$f_{\text {hitung }}>f_{\text {tabel }}$ is $13,139>3,16$, so $H_{0}$ rejected and $H_{1}$ received means that there is a positive effect between communication anxiety towards students' academic achievement of Biology Education Department 2013 in Tarbiyah and Teaching Science Faculty of Alauddin State Islamic University of Makassar with amount $18,5 \%$.
\end{abstract}

Keywords: Communication Anxiety, Academic Achievement

\title{
PENDAHULUAN
}

\section{Latar Belakang Masalah}

Manusia merupakan mahluk sosial yang selalu berinteraksi serta membutuhkan orang lain dalam kehidupannya. Sebagai mahluk sosial, manusia hanya bisa berkembang dan bertahan hidup melalui kerja sama dengan orang lain. Oleh karena itu, diperlukan kecakapan dan kemampuan untuk dapat bergaul dan diterima dengan baik di lingkungan tempat mereka berada. Salah satu wadah untuk melakukan interaksi dengan orang lain adalah dalam dunia pendidikan (Muharomi, 2012: 5).

Pendidikan sebagai salah satu sektor yang paling penting dalam pembangunan nasional, dijadikan andalan utama untuk berfungsi semaksimal mungkin dalam upaya meningkatkan kualitas hidup manusia Indonesia, di mana iman dan takwa kepada Tuhan Yang Maha Esa menjadi sumber motivasi kehidupan segala bidang. Pendidikan 
merupakan suatu kegiatan yang universal dalam kehidupan manusia, sehingga di manapun terdapat masyarakat, di situ pula terdapat pendidikan. Pendidikan itu sendiri merupakan tanggung jawab bersama antara pemerintah, masyarakat, maupun keluarga (Ihsan, 2003:4)

Menurut undang-undang No. 20 Tahun 2003, bab II Pasal 3tentang Sistem Pendidikan Nasional disebutkan bahwa tujuan pendidikan nasional adalah mengembangkan potensi peserta didik agar menjadi manusia yang beriman dan bertakwa kepada Tuhan Yang Maha Esa, berakhlak mulia, sehat, berilmu, cakap, kreatif, mandiri, dan menjadi warga negara yang demokratis serta bertanggung jawab (Prayitno, 2009:259).

Pendidikan merupakan aktivitas yang berlangsung sepanjang hidup manusia agama pun sangat menghendaki setiap umat manusia untuk menempuh pendidikan dan orang yang memiliki ilmu dan pengetahuan akan ditinggikan kedudukannya beberapa derajat, sebagaimana firman-Nya dalam Qs. al-Mujaadilah/58: 11.

\section{Terjemahannya:}

Hai orang-orang beriman apabila kamu dikatakan kepadamu: "Berlapanglapanglah dalam majelis", Maka lapangkanlah niscaya Allah akan memberi kelapangan untukmu. dan apabila dikatakan: "Berdirilah kamu", Maka berdirilah, niscaya Allah akan meninggikan orang-orang yang beriman di antaramu dan orang-orang yang diberi ilmu pengetahuan beberapa derajat. dan Allah Maha mengetahui apa yang kamu kerjakan

Oleh karena itu, dengan adanya pendidikan dapat mengemban tugas hidupnya dengan baik dan penuh tanggung jawab, baik yang berkenaan dengan kepentingan pribadi, masyarakat, bangsa dan negaranya. Winkel (dalam Saefullah, 2011: 171) mengatakan bahwa proses belajar yang dialami oleh mahasiswa menghasilkan perubahan-perubahan dalam bidang pengetahuan dan pemahaman, dalam bidang nilai, sikap, dan keterampilan. Adanya perubahan tersebut tampak dalam prestasi belajar yang dihasilkan oleh mahasiswa terhadap pertanyaan, persoalan, atau tugas yang diberikan oleh dosen melalui prestasi belajar, mahasiswa dapat mengetahui kemajuan yang telah dicapainya dalam belajar.

Prestasi belajar mahasiswa dapat dilihat apabila tujuan-tujuan pembelajaran yang telah ditetapkan dapat dicapai oleh mahasiswa, dan sebaliknya apabila sebagian besar mahasiswa tidak dapat mencapai tujuan-tujuan dari pembelajaran berarti hasil pembelajaran tidak tercapai. Kemampuan berkomunikasi memiliki hubungan yang erat dengan pembelajaran. Kemampuan berkomunikasi penting bagi mahasiswa, karena dengan berkomunikasi menggambarkan bagaimana seseorang dapat memahami, mendengar, dan mampu menyampaikan ide, gagasan dan pengetahuannya kepada orang lain khususnya pada saat melakukan presentase maupun diskusisi yang dilaksanakan hampir setiap hari saat proses belajar mengajar di dalam perguruan tinggi.

Masalah yang banyak dihadapi oleh mahasiswa adalah timbulnya kecemasan pada 
dirinya dalam berkomunikasi. Menurut Philip kecemasan komunikasi adalah perasaan takut untuk ikut berpartisipasi dalam komunikasi lisan pada situasi tertentu. Individu yang mengalami kekhawatiran ketika melakukan hubungan komunikasi dengan orang lain maupun orang banyak berarti merasakan kecemasan dalam berkomunikasi (Reni, 2003: 401)

Penelitian yang dilakukan oleh MC Croskey, memperoleh hasil yang menunjukkan bahwa 10-20\% di Amerika menderita aprehensi komunikasi, yaitu suatu kondisi ketika seseorang merasa cemas untuk melakukan komunikasi dalam berbagai situasi komunikasi, baik formal maupun informal, individual maupun kelompok. Hal tersebut sangat mengganggu aktivitas mereka dalam akademis. Penelitian ini juga menerangkan bahwa orang-orang yang mengalami ketakutan berkomunikasi, cenderung dianggap tidak menarik oleh orang lain dan sangat jarang menduduki jabatan pemimpin. Pada pekerjaan, mereka cenderung tidak puas, di sekolah mereka cenderung malas karena itu mereka cenderung gagal secara akademis

Lebih lanjut hasil penelitian yang dilakukan oleh Hudaniah dan Dayaksini menyatakan bahwa pada umumnya kecemasan itu berwujud ketakutan kognitif, keterbangkitan syaraf fisiologis dan suatu pengalaman subjektif juga dari ketegangan atau kegugupaan. Beberapa individu juga mengalami perasaan tidak nyaman dengan kehadiran orang lain, biasanya disertai dengan perasaan malu, yang ditandai dengan kekakuan, hambatan dan kecenderungan untuk menghindari interaksi sosial. Keadaan Individu yang seperti ini dianggap mengalami kecemasan sosial.

Namun kenyataannya, metode pembelajaran di Fakultas Tarbiyah dan keguruan UIN Alauddin Makassar kebanyakan menggunakan sistem diskusi dan presentasi guna membiasakan mahasiswa berbicara di depan umum. Namun tidak jarang mahasiswa merasa cemas untuk mengungkapkan pikirannya secara lisan, baik pada saat diskusi kelompok, bertanya pada dosen, maupun ketika harus berbicara di depan kelas saat melakukan presentase tugas.

Hal ini dapat diketahui pada saat peneliti melakukan pengamatan awal pada tanggal 18 November 2014, bertempat di kebun biologi. Peneliti melakukan observasi pada 40 mahasiswa semester III Pendidikan Biologi Fakultas Tarbiyah dan Keguruan UIN Alauddin Makassar yang pada saat itu sedang kuliah dengan mata kuliah filsafat umum dan pendidikan dengan metode pembelajarannya diskusi. Hasil pengamatan tersebut dapat dilihat bahwa sebagian besar mahasiswa sering hanya diam diri saja ketika dosen meminta komentar mereka mengenai materi yang baru saja disampaikan. Begitu juga dalam situasi diskusi, hanya orang tertentu saja yang terlibat aktif menginformasikan sesuatu sementara yang lainnya hanya pendengar saja, mereka tidak berani mengemukakan pendapatnya atau menanyakan sesuatu yang belum dipahami.

Hal ini dikarenakan adanya rasa takut menerima tanggapan atau penilaian negatif dari temannya, sehingga menyebabkan mengalami kecemasan berbicara umum yang ditandai dengan kondisi yang tegang, grogi, gemetar saat berbicara dan bahkan malu 
dalam mengeluarkan pendapatnya. Selanjutnya peneliti melihat prestasi akademik mahasiswa pendidikan biologi angkatan 2013 dalam bentuk IPK yang diambil dari portal akademik, terdapat beberapa mahasiswa yang memiliki prestasi akademik yang dapat dikategorikan rendah karena IPK mahasiswa tersebut di bawah 3,00.

Berdasarkan permasalahan tersebut maka penulis sangat tertarik untuk meneliti tentang "Pengaruh Kecemasan Berkomunikasi terhadap Prestasi Akademik Mahasiswa Prodi Jurusan Pendidikan Biologi Fakultas Tarbiyah dan Keguruan UIN Alauddin Makassar Angkatan 2013”.

\section{Rumusan Masalah}

Berdasarkan latar belakang yang telah dipaparkan di atas, maka penulis dapat mengutarakan permasalahan yaitu bagaimana pengaruh kecemasan berkomunikasi terhadap prestasi akdemik mahasiswa Jurusan Pendidikan Biologi Fakultas Tarbiyah dan Keguruan UIN Alauddin Makassar Angkatan 2013?

\section{Tujuan Penelitian}

Sesuai dengan rumusan masalah di atas, maka penelitian ini bertujuan untuk mengetahui pengaruh kecemasan berkomunikasi terhadap prestasi akademik mahasiswa Jurusan Pendidikan Biologi Fakultas Tarbiyah dan Keguruan UIN Alauddin Makassar Angkatan 2013.

\section{Manfaat Penelitian}

Manfaat dari penelitian ini adalah:

a. Manfaat teoritis

1) Dapat memberikan informasi dan menambah khasanah ilmu pengetahuan dalam bidang psikologi khususnya dalam berkomunikasi

2) Dapat digunakan sebagai bahan referensi dan bahan informasi yang dapat digunakan untuk memperoleh gambaran dalam penelitian selanjutnya

b. Manfaat praktis

1) Bagi Dosen. Penelitian ini diharapkan dapat digunakan sebagai bahan pertimbangan bagi dosen jika ingin melakukan penelitian yang sejenis.

2) Bagi Mahasiswa. Penelitian ini diharapkan sebagai tambahan wawasan pengalaman dan pengetahuan yang lebih luas mengenai komunikasi dengan harapan dapat mengurangi perasaan cemas mahasiswa dalam berkomunikasi di lingkungan dimana saja berada serta membentuk konsep diri yang positif.

3) Bagi peneliti selanjutnya. Penelitian ini dapat digunakan sebagai bahan referensi dan bahan informasi yang dapat digunakan untuk pengembangan penelitian yang sejenis bagi peneliti selanjutnya. 


\section{LANDASAN TEORITIS}

\section{Kecemasan Komunikasi}

Pengertian Kecemasan

Kecemasan atau dalam bahasa Inggrisnya "anxiety" berasal dari bahasa Latin “angustus" yang berarti kaku, dan "ango, anci" yang berarti mencekik (Ratih, 2010: $1)$.

Menurut Sigmund Freud kecemasan adalah fungsi ego untuk memperingatkan individu tentang kemungkinan datangnya suatu bahaya sehingga dapat disiapkan reaksi adaptif yang sesuai. Kecemasan berfungsi sebagai mekanisme yang melindungiego karena kecemasan memberi sinyal kepada kita bahwa ada bahaya sehingga dapat disiapkan tindakan yang tepat maka bahayaitu akan meningkat sampai ego dikalahkan (Reni, 2003: 403).

Kecemasan merupakan keadaan emosi yang ditandai secara subjektif, secara sadar merasakan ketegangan, ketakutan, gugup, yang berkaitan dengan sistem saraf otonom. Pendapat lain yang disampaikan Spilberger mengenai kecemasan, ia menyatakan bahwa kecemasan adalah perasaan ketakutan yang ditandai dengan beberapa simtom seperti pusing, mual, gangguan otot, perasaan gelisah dan lemas (Siska, 2003: 68)

\section{Pengertian Kecemasan Komunikasi}

Menurut Hoolbrook kecemasan komunikasi mempunyai banyak istilah yaitu sebagai demam panggung (stage fright), kecemasan komunikasi (communication anxiety), kecemasan tampil di depan umum (performance anxiety), dan kemudian berkembang dengan istilah communication apprehension. communication apprehension di defenisikan sebagai kecemasan atau ketakutan yang di derita oleh individu secara nyata atau antisipasi komunikasi, baik dalam suatu kelompok atau individu dengan individu. Sehingga kecemasan komunikasi akan sangat mempengaruhi komunikasi verbal mereka (Reni, 2003: 404).

Horwitz juga mengemukakan bahwa kecemasan komunikasi merupakan suatu jenis fobiasosial, yang ditandai dengan adanya suatu pemikiran bahwa dirinya akan dikritik atau dinilai jelek oleh orang lain. Seperti yang dikemukakan Rakhmat bahwa orang yang mengalami kecemasan komunikasi akan sedapat mungkin menghindari situasi komunikasi, hal ini karena ia takut orang lain akan mengejeknya atau menyalahkannya.

\section{Aspek Kecemasan Komunikasi}

Menurut Zimbardo dalam Reni (2003; 405) bahwa kecemasan komunikasi mempunyai 5 aspek antara lain:

a. Aspek suasana hati. Aspek-aspek suasana hati dalam gangguan kecemasan adalah kecemasan, tegang, panik dan kekhawatiran, individu yang mengalami kecemasan memiliki perasaan adanya hukuman atau bencana yang akan mengancam dari sumber tertentu yang tidak diketahui.

b. Aspek kognitif. Aspek-aspek kognitif dalam gangguan kecemasan menunjukkan 
kekhawatiran dan keprihatinan mengenai bencana yang diantisipasi oleh individu, misalnya seseorang individu yang takut berada di tengah khayak ramai menghabiskan banyak waktu untukkhawatir mengenai hal-hal yang tidak menyenangkan yang mungkin terjadi dan kemudian merencanakan bagaimana harus menghindari hal-hal tersebut.

c. Aspek somatik. Aspek-aspek somati dari kecemasan dapat dibagi menjadi dua kelompok yaitu pertama adalah aspek-aspek langsung yang terdiri dari keringat, mulut kering, bernapas pendek, denyut nadi cepat, tekanan darah meningkat, kepala terasa berdenyut-denyut, dan otot terasa tegang. Kedua apabila kecemasan berkepanjangan, aspek-aspek tambah seperti tekanan darah meningkat secara kronis, sakit kepala dan gangguan usus (kesulitan dalam pencernaan, dan rasa nyeri pada perut) dapat terjadi.

d. Aspek Afektif yaitu perasaan malu, gelisah dan bingung.

e. Perilaku motorik. Orang-orang yang cemas sering merasa tidak tenang, gugup, kegiatan motorik menjadi tanpa arti dan tujuan misalnya jari-jari kaki mengetukngetuk, bicara patah-patah, tidak banyak bicara, gemetaran, kepala menunduk atau berusaha menghindari tatap mata dan sangat kaget terhadap suara yang terjadi secara tiba-tiba. Aspek aspek motor ini merupakan gambaran rancangan kognitif dan somatik yang tinggi pada individu dan merupakan usah untuk melindungi diri dari apa saja yang dirasanya mengancam.

Berdasarkan uraian tersebut, maka dapat disimpulkan bahwa kecemasan komunikasi mempunyai lima aspek yaitu aspek suasana hati, aspek kognitif, aspek somatik, aspek afektif dan perilaku motorik.

\section{Karakteristik Kecemasan Komunikasi}

Menurut Sri (2014: 50) Individu yang mengalami kecemasan dalam melakukan komunikasi memiliki beberapa karakteristik. Horwitz menerangkan ciri-ciri adanya kecemasan komunikasi, sebagai berikut

a. Ketakutan sebelum dan selama aktivitas atau kegiatan berlangsung

b. Pembangkitan fisiologis (kegelisahan yang ditimbulkan oleh meningkatnya aktivitas sistem saraf otonom)

c. Pembangkit reaksi subjektif pada diri individu

d. Tidak dapat mengendalikan perasaan

e. Ketakutan atau kecemasan dalam menyatakan sesuatu

f. Perasaan takut dinilai orang lain

\section{PRESTASI AKADEMIK}

\section{Pengertian Prestasi Akademik}

Kata "prestasi" berasal dari bahasa Belanda yaitu prestatie. Kemudian dalam bahasa Indonesia menjadi "prestasi" yang berarti "hasil usaha". Istilah "prestasi belajar" (achievement) berbeda dengan "hasil belajar" (learning outcome). Prestasi belajar tidak 
dapat dipisahkan dari berbuatan belajar, karena belajar merupakan suatu proses, sedangkan prestasi belajar adalah hasil dari proses pembelajaran tersebut (Arifin, 2011: 12).

Prestasi Akademik pada umumnya berkenaan dengan aspek pengetahuan, sedangkan hasil belajar meliputi meliputi aspek pembentukan watak peserta didik. Dalam literature, prestasi selalu dihubungkan dengan aktivitas tertentu, seperti dikemukakan oleh Muhibbin Syah menjelaskan bahwa: Prestasi belajar merupakan taraf keberhasilan sebuah proses mengajar-belajar (the teaching-learning process) atau taraf keberhasilan sebuah program pembelajaran/penyajian materi, dan kenaikan kelas (Syah, 2006: 196).

Menurut Reni Akbar, prestasi akademik adalah hasil penilaian pendidik terhadap proses belajar dan hasil belajar mahasiswa sesuai dengan tujuan instruksional yang menyangkut isi pelajaran dan perilaku yang diharapkan dari siswa (Reni, 2012: 168).

Berdasarkan pengertian di atas, maka dapat disimpulkan bahwa prestasi belajar merupakan taraf keberhasilan sebuah proses mengajar belajar (the teaching-learning process) yang dicapai oleh seseorang setelah melakukan kegiatan pembelajaran dan dinyatakan dengan skor atau nilai.

\section{Faktor-Faktor yang Memengaruhi Prestasi Akademik}

Menurut Saefullah (2011: 172) secara garis besarnya faktor-faktor yang dapat mempengaruhi prestasi belajar dapat dikelompokkan atas faktor internal dan faktor eksternal yaitu:

1) Faktor Internal

Faktor yang menyangkut seluruh pribadi termasuk kondisi fisik maupun mental atau psikis. Faktor internal ini sering disebut faktor instrinsik yang meliputi kondisi fisiologi dan kondisi psikologis yang mencakup minat, kecerdasan, bakat, motivasi, dan lain-lain.

a) Kondisi Fisiologis Secara Umum

Kondisi fisiologis pada umumnya sangat berpengaruh terhadap keberhasilan belajar seseorang. Orang yang ada dalam keadaan segar jasmaninya akan berlainan belajarnya dari orang yang ada dalam keadaan lelah. Anak-anak yang kekurangan gizi ternyata kemampuannya berada dibawah anak-anak yang tidak kekurangan gizi. Anak-anak yang kurang gizi mudah lelah, mudah mengantuk, dan tidak mudah menerima pelajaran.

b) Kondisi Psikologis

Belajar pada hakikatnya adalah proses psikologi. Oleh karena itu semua keadaan dan fungsi psikologis tentu saja mempengaruhi belajar seseorang. Itu berarti belajar bukanlah berdiri sendiri, terlepas dari faktor lain seperti faktor dari luar dan faktor dari dalam. Faktor psikologis sebagai faktor dari dalam tentu saja merupakan hal yang utama dalam menentukan intensitas belajar seorang anak. Meski faktor luar mendukung, tetapi faktor psikologis tidak mendukung maka faktor luar itu akan 
kurang signifikan. Oleh karena itu minat, kecerdasan, bakat, motivasi, dan kemampukan-kemampuan kognitif adalah faktor psikologis yang utama mempengaruhi proses dan hasil belajar mahasiswa.

c) Kondisi Panca Indera

Di samping kondisi fisiologis umum, hal yang tak kalah pentingnya adalah kondisi panca indera terutama penglihatan dan pendengaran. Sebagian besar yang dipelajari manusia dipelari menggunakan penglihatan dan pendengaran. Orang belajar dengan membaca, melihat contoh atau model, melakukan observasi, mengamati hasil eksperimen, mendengarkan keterangan guru dan orang lain, mendengarkan ceramah, dan lain sebagainya

d) Intelegensi/Kecerdasan

Intelegensi adalah suatu kemampuan umum dari seseorang untuk belajar dan memecahkan suatu permasalahan. Jika intelegensi seseorang rendah bagaimanapun usaha yang dilakukan dalam kegiatan belajar, jika tidak ada bantuan orang tua atau pendidik niscaya usaha belajar tidak akan berhasil.

e) Bakat

Bakat merupakan kemampuan yang menonjol disuatu bidang tertentu misalnya bidang studi matematika atau bahasa asing. Bakat adalah suatu yang dibentuk dalam kurun waktu, sejumlah lahan dan merupakan perpaduan taraf intelegensi. Pada umumnya komponen intelegensi tertentu dipengaruhi oleh pendidikan dalam kelas, sekolah, dan minat subyek itu sendiri. Bakat yang dimiliki seseorang akan tetap tersembunyi bahkan lama-kelamaan akan menghilang apabila tidak mendapat kesempatan untuk berkembang.

f) Motivasi

Motivasi memegang peranan penting dalam memberikan gairah, semangat, dan rasa senang dalam belajar sehingga yang mempunyai motivasi tinggi mempunyai energy yang banyak untuk melaksanakan kegiatan belajar. Mahasiswa yang mempunyai motivasi tinggi sangat sedikit yang tertinggal dalam belajarnya. Kuat lemahnya motivasi belajar seseorang turut mempengaruhi keberhasilan belajar. Karena itu motivasi belajar perlu diusahakan terutama yang berasal dari dalam diri (motivasi intrinsik) dengan cara senantiasa memikirkan masa depan yang penuh tantangan dan harus untuk mencapai cita-cita. Senantiasa memasang tekat bulat dan selalu optimis bahwa cita-cita dapat dicapai dengan belajar. Bila ada mahasiswa yang kurang memiliki motivasi instrinsik diperlukan dorongan dari luar yaitu motivasi ekstrinsik agar mahasiswa termotivasi untuk belajar.

\section{2) Faktor Eksternal}

Faktor yang bersumber dari luar diri individu yang bersangkutan. Faktor ini sering disebut dengan faktor ekstrinsik yang meliputi segala sesuatu yang berasal dari luar diri individu yang dapat mempengaruhi prestasi belajarnya baik itu di lingkungan sosial maupun lingkungan lain: 
a) Faktor Lingkungan Keluarga

(1) Sosial ekonomi keluarga. Dengan sosial ekonomi yang memadai, seseorang lebih berkesempatanmendapatkan fasilitas belajar yang lebih baik, mulai buku, alat tulis hingga pemilihan sekolah.

(2) Pendidikan orangtua. Orang tua yang telah menempuh jenjang pendidikan tinggi cenderung lebih memperhatikan dan memahami pentingnya pendidikan bagi anak-anaknya, dibandingkan dengan yang mempunyai jenjang pendidikan yang lebih rendah.

(3) Perhatian orangtua dan suasana hubungan antara anggota keluarga. Dukungan dari keluarga merupakan suatu pemacu semangat berprestasi bagi seseorang. Dukungan bisa secara langsung, brupa pujian atau nasihat, ataupun secara tidak langsung, seperti hubungan keluarga yang harmonis.

b) Faktor Lingkungan Sekolah

(1) Sarana dan Prasarana. Kelengkapan fasilitas sekolah, seperti papan tulis, OHP dan sebagainya akan membantu kelancaran proses belajar mengajar di sekolah. Bentuk ruangan, sirkulasi udara, dan lingkungan sekitar sekolah juga dapat mempengaruhi proses belajar mengajar.

(2) Kompetensi guru dan siswa. Kualitas guru dan siswa sangat penting dalam meraih prestasi. Kelengkapan sarana dan prasarana tanpa disertai dengan kinerja yang baikdari para penggunanya akan sia-sia.

(3) Kurikulum dan metode mengajar. Hal ini meliputi materi dan cara memberikan materi tersebut kepada siswa. Metode pembelajaran yang lebih interaktif sangat diperlukan untuk menumbuhkan minat dan peran serta siswa dalam kegiatan pembelajaran.

c) Faktor Lingkungan Masyarakat

(1) Sosial budaya. Pandangan masyarakat tentang pendidikan akan memengaruhi kesungguhan pendidik dan peserta didik. Masyarakat yang masih memandang rendah pendidikan akan enggan mengirimkan anaknya ke sekolah dan cenderung memandang rendah pekerjaan guru.

(2) Partisipasi tehadap pendidikan. Apabila semua pihak telah berpartisipasi dan mendukung kegiatan pendidikan, mulai dari pemerintah (berupa kebijakan dan anggaran) sampai pada masyarakat bawah, setiap orang akan lebih menghargai dan berusaha memajukan pendidikan dan ilmu pengetahuan.

\section{METODOLOGI PENELITIAN}

Jenis penelitian yang digunakan yaitu penelitian deskriptif kuantitatif. Lokasi penelitian bertempat di UIN Alauddin Makassar, tepatnya di Jurusan Pendidikan Biologi Fakultas Tarbiyah dan Keguruan. Kampus ini berlokasi di jalan Sultan Alauddin Nomor 63, Kelurahan Romang Polong, Kecamatan Somba Opu, Kabupaten 
Gowa, Provinsi Sulawesi Selatan. Populasi dalam penelitian ini adalah keseluruhan mahasiswa jurusan Pendidikan Biologi Fakultas Tarbiyah dan Keguruan UIN Alauddin Makassar Angkatan 2013 yang berjumlah 120 orang.

Selanjutnya pengambilan sampel dalam penelitian ini akan dipilih secara acak dengan menggunakan tekhnik "Simple Random Sampling" yaitu peneliti memberikan hak yang sama kepada setiap subjek untuk memperoleh kesempatan dipilih sebagai sampel. Dengan pertimbangan efisiensi dan efektifitas kerja, maka peneliti menetapkan jumlah sampel yang akan digunakan dalam penelitian ini sebanyak 50\% dari 120 orang populasi sebanyak 60 orang.

Metode pengumpulan data dalam penelitian ini adalah menggunakan panduan skala psikologi kecemasan komunikasi mengacu pada teori dari Zimbardo yang terbagi atas 5 aspek yaitu sebagai berikut: Aspek suasana hati, Aspek kognitif, Aspek somatik, Aspespek Afektif, Perilaku motorik dan panduan dokumentasi. Hal ini dimaksudkan untuk mendapatkan data atau informasi yang dapat dipertanggungjawabkan kebenarannya. Instrumen yang dimaksudkan dalam penelitian ini adalah suatu alat ukur yang digunakan dalam penelitian sehingga dapat terlaksana dengan sempurna.

Pengujian validitas dan reliabilitas dalam penelitian ini dengan menggunakan bantuan program SPSS (Statistical Packaged for Social Science) 21 for windows. Hasil uji validitas didaptkan item valid dengan nilai antara 0.334 sampai 0.808 dan nilai reliabilitas sebesar 0.96 termasuk kategori sangat reliable. Metode analisis data yang digunakan dalam penelitian ini adalah analisis deskriptif dan analisis inferensial (regresi sederhana) sesuai dengan rumusan masalah, tujuan dan hipotesis, serta dianalisis inferensial dengan menggunakan bantuan SPSS (Statistical Packaged for Social Science)21for windows. Pengkategorian kecemasan berkomunikasi mahasiswa Jurusan Pendidikan Biologi Fakultas Tarbiyah dan Keguruan Universitas Islam Negeri (UIN) Alauddin Makassar angkatan 2013, penulis menggunakan kategorisasi berdasar model distribusi normal yang merujuk interpretasi skor menurut Saifuddin Azwar (2015: 149) dapat dilihat pada tabel berikut:

Tabel 1: Kategori Skor Kecemasan Komunikasi

\begin{tabular}{|c|c|c|}
\hline Kategori & Rendah & Sedang \\
\hline Nilai & $\mathrm{X}<[\mu-1,0 \sigma]$ & {$[\mu-1,0 \sigma] \leq \mathrm{X}<[\mu+1,0 \sigma]$} \\
\hline $\begin{array}{l}\text { Pengk } \\
\text { Fakultas Ta } \\
\text { angkatan } 20 \\
\text { kelulusan yc } \\
\text { yaitu }\end{array}$ & $\begin{array}{l}\text { orian prestasi } \\
\text { ah dan Kegurua } \\
\text { penulis menggur } \\
\text { merujuk pada } \mathrm{p}\end{array}$ & $\begin{array}{l}\text { emik mahasiswa Jurusan Pendidikan Biologi } \\
\text { versitas Islam Negeri (UIN) Alauddin Makassar } \\
\text { kategorisasi berdasar pada indek prestasi dan nilai } \\
\text { an edukasi UIN Alauddin Makassar (2013: 149) }\end{array}$ \\
\hline
\end{tabular}


Tabel 2: Kategori Skor Prestasi Akademik

\begin{tabular}{ccc}
\hline No. & Interval Skor & Kategori \\
\hline 1 & $3,76-4,00$ & Coumlaude \\
2 & $3,51-3,75$ & Sangat Memuaskan \\
3 & $2,00-3,50$ & Memuaskan \\
\hline
\end{tabular}

(Sumber: Siaka FTK UIN Alauddin Makassar)

\section{HASIL DAN PEMBAHASAN}

Berdasarkan hasil penelitian yang telah dilakukan terhadap mahasiswa angkatan 2013 jurusan pendidkan biologi yang berjumlah 60 mahasiswa, maka penulis dapat mengumpulkan data melalui skalayang diisi oleh mahasiswa itu sendiri. Tingkat kecemasan komunikasi mahasiswa maka dapat diketahui dengan melakukan kategorisasi yang kemudian dinyatakan sebagai acuan atau norma dalam pengelompokan skor individu, yang terlebih dahulu ditetapkan batasannya berdasarkan satuan standar deviasi $(\sigma)$ dan mean teoritisnya $(\mu)$. Berdasarkan hasil analisis deskriptif, maka diperoleh standar deviasi sebesar 11,84 dan nilai rata-rata atau meannya sebesar 82,73, terdapat 9 orang mahasiswa yang memiliki kecemasan dalam berkomunikasi berada dalam kategori rendah dengan persentasi 15\%, 41 orang berada dalam kategori sedang dengan persentase $68,33 \%$, dan 10 orang berada dalam ketegori tinggi dengan persentase sebesar 73,33\%. Sementara itu, jika dilihat dari nilai rata-rata yang diperoleh sebesar 73,6 apabila dimasukkan dalam tiga kategori di atas, maka tingkat kecemasan mahasiswa dalam berkomunikasi berada pada interval 70,89 $\leq \mathrm{X}<$ 94,57 termasuk dalam kategori sedang. Sehingga dapat disimpulkan bahwa mahasiswa Jurusan Pendidikan Biologi angkatan 2013 memiliki tingkat kecemasan dalam berkomunikasi termasuk dalam kategori sedang dengan persentase 68,33\%.

Indeks prestasi (IP) ialah nilai kredit rata-rata yang merupakan satuan nilai akhir yang menggambarkan mutu penyelesaian suatu program. Predikat Kelulusan mahasiswa program sarjana dihitung berdasarkan Indeks Prestasi Kumulatif (IPK) yang diperoleh.

Berdasarkan data yang diperoleh terdapat 4 orang mahasiswa yang prestasi belajarnya masuk dalam kategori cumlaude dengan persentase sebanyak 6,66\%. Sedangkan mahasiswa yang memiliki prestasi akademik dengan kategori yang sangat memuaskan berjumlah 14 orang dengan persentase sebanyak 23,33\%, dan mahasiswa yang termasuk dalam kategori dengan prestasi akademik yang memuaskan berjumlah 42 orang dengan persentase sebanyak 70\%, Berdasarkan hal tersebut, maka dapat disimpulkan bahwa prestasi akademik mahasiswa Jurusan Pendidikan Biologi angkatan 2013 Fakultas Tarbiyah dan Keguruan UIN Alauddin Makassar, berada pada kategori memuaskan dengan persentase $70 \%$, sehingga perlu untuk ditingkatkan lagi agar setidaknya bisa mencapai kategori cumlaude.

Uji normalitas data dimaksudkan apakah data-data yang digunakan berdistribusi normal atau tidak. Pengujian normal tidaknya data pada penelitian ini menggunakan 
statistik SPSS versi 21. Uji normalitas data pada penelitian ini dimaksudkan untuk menguji variabel Kecemasan Berkomunikasi dengan Prestasi Akademik. Pengujian normal tidaknya data pada penelitian ini menggunakan program SPSS Windows melalui uji Kolmogorov Smirnov.

Tabel 3. Hasil Uji Normalitas

\begin{tabular}{lccl}
\hline \multicolumn{1}{c}{ Variabel } & K-SZ & Sig & Keterangan \\
\hline $\begin{array}{l}\text { Kecemasan berkomunikasi } \\
(\mathbf{X})\end{array}$ & 0,682 & 0,741 & Normal \\
Prestasi Akademik $(\mathbf{Y})$ & 0,594 & 0,872 & Normal \\
\hline
\end{tabular}

Berdasarkan uji normalitas dengan menggunakan uji Kolmogorov-Smirnov di atas, diperoleh nilai KSZ untuk variabel X (Kecemasan Komunikasi) sebesar 0,682, dan KSZ untuk variabel Y (prestasi akademik) sebesar 0,594. Nilai Asymp.Sig. (2-tailed) untuk variabel Xsebesar 0,741, dan variabel Y sebesar 0,872. Hasil yang diperoleh lebih besar dari 0,05 $(>0,05)$ maka dapat disimpulkan data berdistribusi normal dan dapat dilanjutkan dengan analisis regresi

Uji linieritas adalah uji yang akan memastikan apakah data yang dimiliki sesuai garis linier atau tidak. Uji linier dilakukan untuk mengetahui apakah variabel independen memiliki hubungan yang linier dengan variabel dependen. Uji linieritas dalam penelitian ini dilakukan dengan menggunakan analisis varians. Kaidah yang digunkan jika Sig. $<\alpha(0,05)$, dan $F_{\text {hitung }}<F_{\text {tabel, }}$ maka hubungan kedua variabel linear. Kesimpulan hasil uji linieritas dapat dilihat pada tabel di bawah ini:

Tabel 4. Hasil Uji Liniearitas

\begin{tabular}{ccccl}
\hline Korelasi & F & Sig & Deviasi & Keterangan \\
\hline $\mathbf{X Y}$ & 0,439 & 0,005 & 0,985 & Linear \\
\hline
\end{tabular}

Berdasarkan pada tabel di atas, diperoleh hasil uji linieritas kecemasan komunikasi terhadap prestasi akademik diperoleh nilai sig. $0,005<\alpha(0,05)$ serta $F_{\text {hitung }}$ $<\mathrm{F}_{\text {tabel }}(0,439<3,16)$ yang berarti data tersebut linear.

Analisis regresi sederhana digunakan untuk melihat pengaruh antara kecemasan berkomunikasi terhadap prestasi akademik mahasiswa Jurusan Pendidikan Biologi angkatan 2013 Fakultas Tarbiyah dan Keguruan UIN Alauddin Makassar, dengan kata lain untuk menguji hipotesis yang diajukan. Selain itu, analisis korelasi (R) digunakan untuk mengetahui hubungan antara satu variabel independen (X) terhadap variabel dependen (Y). Koefisien ini menunjukkan seberapa besar hubungan yang terjadi antara variabel independen $(\mathrm{X})$ terhadap variabel dependen $(\mathrm{Y})$. Nilai $\mathrm{R}$ berkisar antara 0 sampai 1, jika nilai semakin mendekati 1 berarti hubungan yang terjadi semakin kuat, sebaliknya nilai semakin mendekati 0 maka hubungan yang terjadi semakin lemah. 
Tabel 5: Interpretasi koefisien korelasi nilai $\mathbf{r}$

\begin{tabular}{ccc}
\hline No & Tingkat Korelasi & Kategori \\
\hline 1 & $0,80-1,00$ & Sangat kuat \\
2 & $0,60-0,799$ & Kuat \\
3 & $0,40-0,599$ & Cukup \\
4 & $0,20-0,399$ & Rendah \\
5 & $0,00-0,199$ & Sangat rendah \\
\hline
\end{tabular}

Berdasarkan aplikasi analisis SPSS 21 diperoleh kesimpulan hasil analisis yaitu sebagai berikut:

Tabel 6: Hasil Analisis Regresi Sederhana

\begin{tabular}{rrrrl}
\hline $\mathbf{r}_{\mathbf{x y}}$ & $\mathbf{r}^{\mathbf{2}}$ & $\mathbf{F}$ & $\mathbf{S i g}$ & Kesimpulan \\
\hline $\mathbf{- 0 , 4 3 0}$ & 0,185 & 13,139 & 0,001 & $\begin{array}{l}\text { Berkorelasi positif } \\
\text { signifikan }\end{array}$ \\
& & & & . \\
\hline
\end{tabular}

Berdasarkan hasil analisis data yang dilakukan, dapat disimpulkan bahwa terdapat pengaruh positif yang signifikan (sig. $<0,05$ ) antara kecemasan berkomunikasi terhadap prestasi akademik mahasiswa Jurusan Pendidikan Biologi angkatan 2013 Fakultas Tarbiyah dan Keguruan UIN Alauddin Makassar.

Berdasarkan hasil analisis tersebut diperoleh nilai $\mathrm{R}$ sebesar -0,430. Hal ini menunjukkan bahwa terjadi hubungan yang cukup erat antara kecemasan berkomunikasi terhadap prestasi akademik mahasiswa. Analisis determinasi dalam regresi sederhana digunakan untuk mengetahui presentase sumbangan pengaruh variabel independen $(\mathrm{X})$ terhadap variabel dependen $(\mathrm{Y})$. Koefisien ini menunjukkan seberapa besar presentase variabel independen yang digunakan dalam model mampu menjelaskan variabel dependen. Jika $\mathrm{R}^{2}$ sama dengan 0 , maka tidak ada sedikitpun presentase sumbangan pengaruh yang diberikan variabel independen terhadap variabel dependen, atau variabel independen yang digunakan dalam model tidak menjelaskan sedikitpun variabel dependen. Sebaliknya jika $\mathrm{R}^{2}$ sama dengan 1 , maka presentase sumbangan pengaruh yang diberikan variabel independen terhadap variabel dependen adalah sempurna atau variabel independen yang digunakan dalam model menjelaskan $100 \%$ variabel dependen.

Berdasarkan tabel diperoleh angka $\mathrm{R}^{2}$ ( $\mathrm{R}$ Square) sebesar 0,185 atau (18,5\%). Hal ini menunjukkan bahwa presentase sumbangan kecemasan berkomunikasi terhadap prestasi akademik mahasiswa sebesar $18,5 \%$ sedangkan sisanya sebesar $81,5 \%$ dipengaruhi atau dijelaskan oleh variabel lain yang tidak dimasukkan dalam penelitian ini.

Kecemasan komunikasi merupakan suatu jenis fobiasosial, yang ditandai dengan adanya suatu pemikiran bahwa dirinya akan dikritik atau dinilai jelek oleh orang lain yang biasanya berupa ketakutan, tegang, gugup, panik dan rasa kekhawatiran, berupa 
perasaan negatif yang dirasakan individu dalam melakukan komunikasi. Seperti yang dikemukakan Rakhmat bahwa orang yang mengalami kecemasan komunikasi bukanlah satu masalah apabila masih berada dalam taraf normal, namun apabila kecemasan komunikasi yang dialami berada dalam tingkat tinggi, maka individu akan menghadapi masalah kepribadian, seperti usaha untuk selalu menghindari komunikasi dengan orang lain

Kecemasan berkomunikasi bisa saja berpengaruh terhadap prestasi akademik mahasiswa Jurusan Pendidikan Biologi karena perasaan cemas, takut, khawatir dan panik merupakan sifat yang tidak bisa dipungkiri pasti setiap individu mengalaminya. Jadi prestasi akademik peserta didik bisa saja tinggi atau rendah tergantung bagaimana mahasiswa mampu mengontrol diri untuk meningkatkan rasa kepercayaan diri dan mengurangi perasaan cemas dalam berkomunikasi. Mahasiswa Jurusan Pendidikan Biologi angkatan 2013 memiliki kecemasan berkomunikasi yang berada pada kategori sedang dengan presentase sebesar $68,33 \%$. Karakteristik individu yang mengalami kecemasan dalam berkomunikasi dapat dilihat bahwa adanya penghindaran, penarikan diri, ketidaknyamanan internal, dan overcommunication.

Banyak mahasiswa akan menghindari atau menarik diri pada situasi atau keadaan yang memerlukan komunikasi. Dapat dilihat bahwa mahasiswa jurusan pendidikan biologi angkatan 2013 yang mengalami kecemasan komunikasi akan memilih untuk tidak terlibat dan tidak ikut berada dalam situasi yang membutuhkan komunikasi. Contoh perilaku penghindaran yaitu pada saat proses pembelajaran berlangsung terdapat mahasiswa yangkurang aktif dalam mengeluarkan pendapat dan bertanya ketika diskusi kelompok atau presentase berlangsung, mereka mengeluarkan pendapat jika diminta oleh dosen untuk berkomentar. Hal tersebut dapat dibuktikan dengan hasil penelitian bahwa kecemasan berkomunikasi mahasiswa Pendidikan Biologi Fakultas Tarbiyah dan Keguruan UIN Alauddin Makassar angkatan 2013 berada pada kategori sedang dengan presentase sebesar $68,33 \%$.

Penghindaran atau penarikan diri ini berpengaruh terhadap prestasi akademik mahasiswa Jurusan Pendidikan Biologi angkatan 2013 Fakultas Tarbiyah dan Keguruan UIN Alauddin Makassar karena dengan adanya sifat ini,mahasiswa akan merasa dirinya tidak mampu mengeluarkan tanggapan atau ide pada saat berdiskusi yang kemudian membuatnya berdiam diri sehigga hal tersebut akan berpengaruh terhadap prestasi belajar mereka.

Ketidaknyamanan internal merupakan salah satu hal yang bisa mempengaruhi prestasi akademik karena individu yang mengalami perasaan tidak nyaman dalam diri ketika menghadapi peristiwa yang membutuhkan komunikasi, mendapat rangsangan negatif untuk melakukan komunikasi dalam situasi komunikasi, rangsangan tersebut berhubungan dengan perasaan takut, gelisah, tidak tenang, dan tegang ketika proses pembelajaran berlangsung dimana giliran mahasiswa untuk berbicara dan mempresentasekan tugas yang diberikan, maka timbullah perasaan takut, khawatir dan 
bahkan panik dari dalam diri mahasiswa ketika waktu untuk berkomunikasi tersebut semakin dekat. Hal tersebut bisa saja mempengaruhi prestasi belajar mahasiswa tersebut.

Berdasarkan pada uraian di atas, maka dapat disimpulkan bahwa kecemasan berkomunikasi berpengaruh terhadap prestasi akademik. Hasil yang diperoleh pada penelitian ini telah sesuai dengan teori yang dikemukakan oleh Rakhmat yang mengatakan bahwa salah satu faktor yang mempengaruhi prestasi belajar adalah sifatsifat pribadi seseorang. Lebih jelas diungkapkan dari hasil penelitian oleh MC Croskey, memperoleh hasil yang menunjukkan bahwa 10-20\% di Amerika menderita aprehensi komunikasi, yaitu suatu kondisi ketika seseorang merasa cemas untuk melakukan komunikasi dalam berbagai situasi komunikasi, baik formal maupun informal, individual maupun kelompok. Hal tersebut sangat mengganggu aktivitas mereka dalam akademis. Penelitian ini juga menerangkan bahwa orang-orang yang mengalami ketakutan berkomunikasi, cenderung dianggap tidak menarik oleh orang lain dan sangat jarang menduduki jabatan pemimpin. Pada pekerjaan, mereka cenderung tidak puas, di sekolah mereka cenderung malas karena itu mereka cenderung gagal secara akademis

Hasil penelitian ini juga sejalan dengan hasil penelitian yang dilakukan oleh Hudaniah dan Dayaksini menyatakan bahwa pada umumnya kecemasan itu berwujud ketakutan kognitif, keterbangkitan syaraf fisiologis dan suatu pengalaman subjektif juga dari ketegangan atau kegugupan. Beberapa individu juga mengalami perasaan tidak nyaman dengan kehadiran orang lain, biasanya disertai dengan perasaan malu, yang ditandai dengan kekakuan, hambatan dan kecenderungan untuk menghindari interaksi sosial. Keadaan Individu yang seperti ini dianggap mengalami kecemasan sosial. Oleh karena itu dapat disimpulkan bahwa penelitian yang dilakukan oleh peneliti sejalan dengan hasil penelitian sebelumnya yang menyatakan bahwa pada umumnya kecemasan itu berwujud ketakutan kognitif, keterbangkitan syaraf fisiologis dan suatu pengalaman subjektif juga dari ketegangan atau kegugupan disertai dengan perasaan malu, mengganggu kegiatan akademis yang pada akhirnya menyebabkan kegagalan secara akademis.

Berdasarkan hasil pengujian hipotesis yang memperlihatkan bahwa nilai $\mathrm{F}$ yang diperoleh dari hasil perhitungan $\left(\mathrm{F}_{\text {hitung }}\right.$ ) lebih besar daripada nilai $\mathrm{F}$ yang diperoleh dari tabel distribusi $\mathrm{F}\left(\mathrm{F}_{\text {tabel }}\right)$ dengan taraf signifikansi sebesar 5\% $\quad \mathrm{F}_{\text {hitung }}>\mathrm{F}_{\text {tabel }}(13,139>$ 3,16) serta merujuk pada penelitian sebelumnya yang relevan, membuktikan bahwa terdapat pengaruh yang signifikan antara kecemasan berkomunikasi terhadap prestasi akademik mahasiswa Jurusan Pendidikan Biologi angkatan 2013 Fakultas Tarbiyah dan Keguruan Universitas Islam Negeri (UIN) Alauddin Makassar sebesar 18,5\% dan sisanya $81,5 \%$ dipengaruhi oleh faktor lain seperti motivasi, penyesuaian diri, pola asuh orang tua, gaya mengajar, citra diri, kepercayaan diri dan lain-lain. 


\section{KESIMPULAN}

Berdasarkan hasil penelitian dan pembahasan, maka dapat ditarik kesimpulan Berdasarkan hasil analisis statistik inferensial kecemasan berkomunikasi berpengaruh negative $(\mathrm{R}=-0.430)$ terhadap prestasi akademik mahasiswa Jurusan Pendidikan Biologi angkatan 2013 Fakultas Tarbiyah dan Keguruan Universitas Islam Negeri (UIN) Alauddin Makassar, karena semakin tinggi kecemasan komunikasi maka menyebabkan prestasi akademik menurun dan begitu pula sebaliknya. Sumbangan pengaruh variabel kecemasan berkomunikasi sebesar $18,5 \%$ dan sisanya $81,5 \%$ dipengaruhi oleh variabel lain yang tidak dimasukkan dalam penelitian ini.

\section{DAFTAR PUSTAKA}

Arifin, Zainal. Evaluasi Pembelajaran. Cet. IV; Bandung: Remaja Rosdakarya, 2011. Azwar, Saifuddin. Penyusunan Skala Psikologi. Jakarta: Remaja Rosda Karya, 2015.

Dinas Pendidikan dan Kebudayaan. Dasar-dasar Ilmu Pendidikan. Jakarta: Raja Grafindo Pustaka, 2005.

Dwi, Watoyo. "Hubungan Antara Lingkungan Belajar Dan Minat Belajar Siswa dengan Prestasi Belajar Mata Pelajaran Akuntansi Kelas Xi Jurusan Ips Sma Negeri I Paninggaran Kabupaten Pekalongan Tahun 2008," Thesis. Surakarta: Pascasarjana, Universitas Sebelas Maret, 2008.

Femi, Olivia. Teknik Ujian Efektif. Cet. 1;Jakarta: PT. Elex Media Komputindo, 2011.

Fuad, Ihsan. Dasar-Dasar Kependidikan, Cet. III; Jakarta: Rineka Cipta, 2003.

Feist Jess dan Gregory J. Feist, Teori Kepribadian, Jakarta: Salemba Humanika, 2010.

Hakim,Thursan. Belajar secara Efektif. Cet. 1; Jakarta: Pustaka Pembangunan Swadaya Nusantara, 2005.

Hasan M. Iqbal. Pokok-Pokok Materi Statistik. Jakarta: Bumi Aksara, 2008

Imron, Rosidi. Menulis Siapa Takut?, Cet. V; Yogyajarta: Kanisius, 2013.

Natsir, Moh. Metode Penelitian. Jakarta: Ghalia Indonesia, 2003.

Purbayu. Analisis Statistik dengan MS. Excel. Jakarta: Bumi Aksara, 2008.

Prayitno. Dasar Teori dan Praksis Pendidikan, Cet. II; Padang: Grasindo, 2009.

Rakhmat, Jalaluddin. Psikologi komunikasi. Bandung: Remaja Rosda Karya, 2008.

Reni, Akbar. Akselerasi, Cet. 1; Jakarta: Grafindo, 2012.

Rizkhi, Ika. "Analisis Pengaruh Proses Belajar Mengajar, Motivasi Belajar, dan Lingkungan Belajar Kampus terhadap Prestasi Belajar Mahasiswa”. Skripsi. 
Semarang:Fakultas Ekonomika dan Bisnis, Universitas Diponegoro, 2013.

Sevilla, Counselo. Pengantar Metodologi Penelitian. Jakarta: UI-Press, 1993.

Siregar, Sofyan. Statistik Deskriptif untuk Penelitian. Jakarta: Raja Grafindo Pusaka, 2011.

Slameto. Belajar dan Faktor-faktor yang Mempengaruhinya, Cet. V; Jakarta : Rineka Cipta, 1988.

Sugiyono. Metode Penelitian Kuantitatif Dan Kualitatif Dan $R \&$ D, Cet. VI; Bandung: Alfabeta, 2009.

Syah, Muhibbin. Psikologi Belajar. Cet. II; Jakarta : Raja Grafindo Persada, 2006.

Saefullah. Psikologi perkembangan dan Pendidikan. Bandung: Pustaka Setia, 2012.

Supranto, J. Statistik Teori dan Aplikasi. Jakara: Erlangga, 2008.

Steven, Beebe. A. Interpersonal Communication. Boston: Allyn and Baccon, 2005.

Siska, dan Sudardjo. "Kepercayaan Diri Dan Kecemasan Komunikasi Interpersonal Pada Mahasiswa.” Jurnal Psikologi, vol. 1 no. 02 (2003).

Tohirin. Psikologi Pembelajaran Pendidikan Agama Islam. Jakarta: Raja Grafindo Persada, 2006.

Winkel, W.S. Psikologi Pengajaran, Edisi Revisi. Jakarta: Raja Grasindo Persada, 1999.

Winarni, Reni. “ Kepercayaan Diri dengan Kecemasan Komunikasi di Depan Umum Pada Mahasiswa”. Jurnal Online Psikologi, vol. 01 No. 02 (2003). http:// ejournal.umm.ac.id 